University of Pennsylvania Carey Law School

Penn Law: Legal Scholarship Repository

Faculty Scholarship at Penn Law

7-26-2003

\title{
"Black People's Money": The Impact of Law, Economics, and Culture in the Context of Race on Damage Recoveries
}

Regina Austin

University of Pennsylvania Carey Law School

Follow this and additional works at: https://scholarship.law.upenn.edu/faculty_scholarship

Part of the Civil Rights and Discrimination Commons, Inequality and Stratification Commons, Law and Economics Commons, Law and Race Commons, Law and Society Commons, Litigation Commons, Other Economics Commons, Race and Ethnicity Commons, Social and Cultural Anthropology Commons, and the Work, Economy and Organizations Commons

\section{Repository Citation}

Austin, Regina, "'Black People's Money": The Impact of Law, Economics, and Culture in the Context of Race on Damage Recoveries" (2003). Faculty Scholarship at Penn Law. 1674.

https://scholarship.law.upenn.edu/faculty_scholarship/1674

This Article is brought to you for free and open access by Penn Law: Legal Scholarship Repository. It has been accepted for inclusion in Faculty Scholarship at Penn Law by an authorized administrator of Penn Law: Legal Scholarship Repository. For more information, please contact PennlawIR@law.upenn.edu. 


\section{Draft-Money Paper}

Regina Austin - Penn Law

\section{"BLACK PEOPLE'S MONEY": THE IMPACT OF LAW, ECONOMICS, AND CULTURE in the CONTEXT OF RACE ON DAMAGE RECOVERIES}

\section{(1) Introduction}

In this Essay, I set out to prove that there is such a thing as "black people's money” and that it is worth less than white people's money, both socially and materially. The truth of these propositions has important implications for any area of law in which equality of monetary outcomes between similarly-situated blacks and whites is the goal. My focus will be on tort damages. I will begin with an analysis of two cases in which I argue that the tort recoveries of the black plaintiffs reflect the lesser social and material value attached to black people's money. From there, I will offer a broad discussion of the concept of the social meaning or value of money in order to show that, as a general matter, money lacks an intrinsic worth that is immune to the impact of racism and ethnocentrism. On the contrary, money's value is highly contingent and highly contestable.

I will employ a crude, simplistic economic model to illustrate how black people’s money, like a foreign currency, is created and its exchange value calculated and maintained vis-á-vis white people’s money. I basically contend that black people’s money is an artifact of segregated markets and color-conscious commercial transactions that proceed against the backdrop of common cultural understandings about the value of black people's money. In the next section of the Essay, I explore the cultural mechanisms that work to make black people's money distinctive from and worth less than white people's money. I maintain that black people's money is like a fetish subject to a taboo or an implicit understanding shared by whites, blacks, and others that money will not be put to its best, highest, or most efficient use in the hands of blacks who are considered undeserving of its beneficence. Relieving blacks of their money, almost by any available means, breaks the taboo and restores money to its sacred state and full value. In addition to resting on a generalized admonition to this effect, the taboo has a morespecific 


\section{Draft-Money Paper}

\section{Regina Austin - Penn Law}

manifestation in the association between black people's money and cash, the most primitive and least substantial form of money. In small amounts, cash is considered petty and in large amounts it is considered evidence of crime. Stereotypes that underestimate the amount of money blacks have at their disposal or that cast doubt on the legitimacy of the ways in which blacks make their money (i.e., by such dubious means as crime, dishonesty, athleticism, or affirmative action) promote the belief that blacks are not deserving of the money they possess and furthermore do not know how to maximize its value. Such beliefs in turn facilitate negotiations and business practices that assure that black people's money will be worth less than white people's money.

Unfortunately, blacks' attitudes about their own money have been shaped by the dictates of the cash economy to which many poor and working class blacks are still relegated, not as a matter of choice, but on account of institutional exclusion. Moreover, as I will show, the habits and attitudes of middle-class blacks regarding money also bear the marks of a history of economic discrimination and socialization in the dictates of the restricted cash economy.

Finally, in the conclusion, there are some suggestions or strategies by which black plaintiffs might counteract the impact of the social value of their money on their damage recoveries. More importantly, the essay ends with a plea that black people look upon money as the repository of their history of exploitation and of contribution to the productivity of America. I call upon them to take on the task of humanizing money, by making its institutions and its actors accountable for failing to meet the needs and concerns of the least well off among us.

What follows is more of a speculative essay or meditation on black people's money than a definitive proof of its existence and lesser worth. In embarking on this analysis, the reader should understand that, as far as I have been able to determine, there has been no extended analysis of the social meaning of black people's money in the literature of law, anthropology, sociology, economics, or cultural studies. For want of the benefit of critical multidisciplinary work on the subject of black people's money and its 


\section{Draft-Money Paper}

\section{Regina Austin - Penn Law}

May 15, 2012

worth, the conclusions that follow are tentative and intended to start a dialogue, not to end one.

\section{(2) Mrs. Wright's Money}

During jury deliberations in the case of Wright $v$. CTL Distribution, Inc., ${ }^{1}$ a civil action arising out of a traffic accident, several of the jurors reportedly said that "they did not want to award anything to [the plaintiff] because she was a fat black woman on welfare who would simply blow the money on liquor, cigarettes, jai alai, bingo or the dog track." 2 They also suggested that they, presumably as taxpayers or insureds, "would be paying one way or another, by awarding money in this case or through welfare.”3 According to her attorney, the plaintiff, Joann R. Wright, had indeed been on welfare at some point, but had gone back to school, gotten a job as a nurse's aide, and turned her life around. ${ }^{4}$ At the time of the accident, she was receiving workers' compensation for an employment-related injury. She had been scheduled to return to work when her automobile was hit by defendant's truck as it was changing lanes. Plaintiff lost control of her vehicle and collided with a building. ${ }^{5}$ The all-white jury which included those who made the derogatory comments found that Mrs. Wright was $70 \%$ at fault, which greatly reduced her recovery. ${ }^{6}$ The opinion does not disclose the amount of damages the jurors awarded her.

${ }^{1} 650$ So. 2d 641 (Fla. Ct. App.1995); 679 So. 2d 1233 (Fla. Ct. App.1996).

${ }^{2} 650$ So. $2 d$ at 642.

${ }^{3} 679$ So. $2 \mathrm{~d}$ at 1234.

${ }^{4}$ Telephone Conversation with Kenan George Dandar, Esq., attorney for Joann R. Wright (August 30, 2001). Mrs. Wright testified to the impact that "being saved" had had on her recreational activities. Id.

${ }^{5} 679$ So. 2d at 1233.

${ }^{6} 650$ So. 2d 642. To limit Mrs. Wright's recovery, the jury could either reduce the amount of damages incurred by her or increase the amount of fault assigned to her conduct. 


\section{Draft-Money Paper}

\section{Regina Austin - Penn Law}

May 15, 2012

The trial judge refused to order a jury interview based on the sworn affidavit of a juror who overheard the negative remarks made about Mrs. Wright. The Florida District Court of Appeal reversed and remanded with the instruction that plaintiff be given a new trial if misconduct were established. ${ }^{7}$

On remand, the testimony of three of the six jurors confirmed that "racially stereotypical comments and discussions occurred before and during jury deliberations.”8 A fourth juror asserted that "any comments were made more in jest than anything.” The trial court concluded that the statements were innocuous: Yes, reference had been made to plaintiff's race, sex, and recreational activities, but "[t]hese matters were not discussed in a prejudicial manner or with any malice. . . " ${ }^{9}$ The trial judge stated that all jurors come to the job with biases and prejudices, yet history suggests that jurors can get beyond their flaws to render just and fair verdicts. "Important in the attainment of that goal," reasoned the court, "is the free and open exchange of ideas and discussion in the jury room, unbridled with concerns of not speaking politically correct and possibly offending someone who feels strongly about some aspect of life.” ${ }^{10}$ The trial judge suggested that if behavior that does not play a role in the decision becomes a basis for overturning a verdict, then "jurors should be warned to keep all opinions to themselves and carefully sanitize their statements," particularly those pertaining to “sex, race, occupation, age, height, weight, recreational activities, residency, place of birth, hair style, hair color, eye color, clothing, religion, party affiliation, or number of children just to name a few.”

The appellate court again saw the matter differently. It was concerned that articulated prejudices not infect the fairness of the deliberative process. It asserted that

\footnotetext{
${ }^{7} 650$ So. $2 d$ at $643-44$.

${ }^{8} 679$ So. $2 \mathrm{~d}$ at 1234.

${ }^{9} I d$.

${ }^{10} I d$.
} 


\section{Draft-Money Paper}

\section{Regina Austin - Penn Law}

May 15, 2012

“[o]nly through constant vigilance by those in positions of authority, to bring forth, to encourage, and to uphold the highest aspects of our humanity, can we continue to progress toward that elusive goal of a society of citizens equal in all respects before the law, rich or poor, black, brown, red, yellow or white.”11 The verdict was overturned and remanded for a retrial. ${ }^{12}$

The statements attributed to some of the jurors in the Wright case suggest that they felt justified in diminishing the amount of plaintiff's recovery because of how, but for the accident, she made her money. They dismissed her effort to secure wages from gainful (albeit perhaps poorly paid) employment and her entitlement to workers' compensation benefits; furthermore they linked the welfare payments she had received in the past with the monetary damages they might award her. Feeling themselves to be either morally superior to plaintiff and/or protectors of the collective wealth, the jurors talked about the money that they might award her or that she received as social welfare benefits as if both came or were coming from their own pockets. Plaintiff was accordingly beholden to them and their class for any money she had, whatever form it took, and the jurors in turn felt justified in keeping a tight rein on the purse strings. ${ }^{13}$

${ }^{11} I d$.

${ }^{12}$ The second jury assessed Mrs. Wright's damages at \$85,000, but found her to be $90 \%$ at fault. This jury too was all white. Telephone Interview with Kenan George Dandar, supra note $\underline{4}$.

${ }^{13}$ The jurors' attitudes toward damages for Mrs. Wright are reminiscent of those explored in David M. Engel's classic ethnographic study of a changing agricultural county in Illinois that had low rates of litigation, but high levels of negative concern about it. David M. Engel, The Oven Bird's Song: Insiders, Outsiders, and Personal Injuries in an American Community, in Law and Community in Three American Towns 27 (Carol J. Greenhouse et al. eds., 1994). Engel found that litigation was a site of cultural conflict in a community that was experiencing an influx of union members, ethnic minorities, southerners, and southwesterners, id. at 29-30; attitudes toward litigation and damages accordingly reflected the shifting social structure and challenges to the traditional order. $I d$. at 47. Old-timers stigmatized litigants and excluded them from the same moral universe as a way of maintaining a social distance from them. $I d$. at 53. The litigants tended to be outsiders or newcomers without extensive social networks through 


\section{Draft-Money Paper}

\section{Regina Austin - Penn Law}

May 15, 2012

Moreover, the jurors also assumed that plaintiff would squander any damages awarded her by eating to excess, drinking, smoking, and gambling the rest away. ${ }^{14}$ The jurors distrusted plaintiff as a successful recipient of tort damages in much the same way that mothers receiving public assistance have been distrusted to spend their welfare allotments. (Indeed, they likened Mrs. Wright to a welfare recipient although she was no longer collecting benefits.) Debates have occurred continuously in this country since the early 1800s -- long before there were "welfare queens" -- over the form public charity or public assistance should take. ${ }^{15}$ Social policy theorists and welfare professionals have shifted back and forth over time between favoring in-kind benefits like food stamps on the one hand and cash payments on the other in their struggle with the poor over the poor's competence to spend the funds allotted them. The choice between these two forms of "contested money" has depended as much on an assessment of the morality of the poor's consumption preferences as on the efficiency of one mode of delivering benefits over the other.

which disputes could be resolved without resorting to the courts. Id. at 44. Moreover, among the old-timers, damages were considered an improper "cashing in." "Money was viewed as something one acquired through long hours of hard work, not by exhibiting one's misfortunes to a judge or jury or other third party, even when the injuries were clearly caused by the wrongful behavior of another." Id. at 33-34.

${ }^{14}$ Mrs. Wright's actual or assumed leisure activities may have seemed all the more offensive to the jurors because of how she earned her money. Black leisure is often treated like an entitlement that must be hard or well-earned. See generally Regina Austin, "Not Just for the Fun of It!": Governmental Restraints on Black Leisure, Social Inequality, and the Privatization of Public Space, 71 S. Cal. L. Rev. 667, 699-700 (1998) [hereinafter Austin, Governmental Restraints on Black Leisure].

${ }^{15}$ See generally Viviana A. Zelizer, The Social Meaning of Money 119-98 (1994) (exploring the various ways in which charitable contributions to the poor have historically been contested monies). The debate continues over the appropriate form social welfare benefits should take. See Martha B. Coven, The Freedom to Spend: The Case for Cash-Based Public Assistance, 86 Minn. L. Rev. 847 (2002) (arguing that public assistance in the form of cash not only is more efficient in that it allows for expenditures based on recipients' preferences, but also better respects the dignity and autonomy of recipients than in-kind aid or restricted transfers). 


\section{Draft-Money Paper}

\section{Regina Austin - Penn Law}

May 15, 2012

Finally, note that the jurors did not consider that Mrs. Wright might have saved the damage award or used the money to make an investment in a substantial asset like a home or a college education for herself or her children. ${ }^{16}$ Of course, the thought of plaintiff's making a more profitable use of her tort recovery and thereby boosting her class standing might also have offended the jurors.

The attitudes that the jurors expressed were ones that were guaranteed to reproduce Mrs. Wright's social and economic standing at best or to leave her less well off than she had been before the accident at worst. The benefits or wages Mrs. Wright's damage award was supposed to replace already reflected the low market value accorded her labor. This may have been lost on the jurors who seemed inclined to diminish its worth even further. Moreover, viewing themselves as the ultimate source of the money to be paid as damages was not likely to make the jurors generous. Passing judgment on the propriety, or in this case impropriety, of how the jurors imagined the plaintiff would spend the damage award at the same time that they were determining the amount she would receive could only decrease Mrs. Wright's recovery.

Though the jurors’ explicit reference to plaintiff's race very likely left the appellate court little choice but to invoke the ideal of formal color-blind equality, ${ }^{17}$ there was otherwise something quite ordinary and normal, even “natural,” about the jurors' attempt to value the money they were about to award plaintiff in terms of the context or fabric of her presumed work life and consumption habits. In expressing reluctance or aversion to awarding substantial damages to a black woman because of their assumptions about who she was, where her money came from, and what she would do with it, the

\footnotetext{
${ }^{16}$ Black women's wealth acquisition is not generally supported by governmental policy or cultural norms and practices. See generally Regina Austin, Nest Eggs and Stormy Weather: Law, Culture, and Black Women's Lack of Wealth, 65 U. Cin. L. Rev. 767 (1997).

${ }^{17}$ See Craig B. Willis, Juror Misconduct: Balancing the Need for Secret Deliberations with the Right to a Fair and Impartial Trial, Fla. Bar J., May 1998, at 20, 24-25 (describing the evolution of the Florida Supreme Court's treatment of jurors' racial comments as overt acts of misconduct, as opposed to impressions or opinions that inhere in the verdict).
} 


\section{Draft-Money Paper}

\section{Regina Austin - Penn Law}

May 15, 2012

jurors were drawing upon a widespread understanding of the social meaning that attaches

to money, a social meaning that has a profound impact on black people's material wellbeing.

Thus, the jurors in the Wright case, much like the rest of us, essentially saw the money they were being asked to dispense, not in purely economic terms, but in cultural and social terms as well, which is, perforce to say in this society, in socially and economically stratified, and racially and sexually discriminatory terms. ${ }^{18}$ This may explain why the trial court and some of the jurors found little wrong with their statements. Indeed, if tort damages are supposed to restore, as nearly as possible, the pre-accident socioeconomic status quo, then the jurors in the Wright case may have been on to something in their effort to take into account extraneous factors like race, gender, and class that affect the valuation of money. Their sin consisted of their expressing their biases aloud, as opposed to merely letting them operate sub silentio. ${ }^{19}$ The latter

${ }^{18}$ The inappropriate impact of the social valuation of money on jurors' decisions is also reflected in the concept of "deep pockets." "Deep pockets” are "substantial wealth or resources against which a claim may be made or a judgment may be taken.” Black's Law Dictionary 425 (7th ed. 1999). Wealth is not supposed to be a basis on which liability is determined or damages (other than punitive damages) assessed. Jury studies, however, suggest that jurors do consider whether the plaintiff or the defendant is likely to be insured and whether the defendant is an individual or corporation. See Nicole L. Mott, Valerie P. Hans, \& Lindsey Simpson, What's Half a Lung Worth? Civil Jurors' Accounts of Their Award Decision Making, 24 Law \& Human Behav. 401, 412, 415-16 (2000) (describing the factors considered during jury deliberations of tort and contracts cases as reported by actual jurors in posttrial interviews). It appears that jurors also consider the plaintiff's obligation to pay attorney's fees even though they are not instructed to do so. Id. at 411, 415.

${ }^{19}$ If, as this Essay argues, an anti-black money bias exists, jurors are not the only parties to the tort litigation process acting on it. There is some empirical support for the proposition that black plaintiffs recover less often and lower amounts than comparably situated white plaintiffs. See Audrey Chin \& Mark A. Peterson, Deep Pockets, Empty Pockets: Who Wins in Cook County Jury Trials (Rand Institute for Civil Justice 1985) (reporting results of a statistical study of 9000 civil jury trials conducted between 1959 and 1979). Attorneys who represent black plaintiffs also claim that racial discrimination reduces the dollar amounts at which defendants and insurance claims adjustors value tort claims brought by blacks, the dollar amounts offered blacks in settlement, and the dollar amounts ultimately awarded blacks by judges, in addition to 


\title{
Draft-Money Paper
}

\section{Regina Austin - Penn Law}

May 15, 2012

approach, of course, is no less problematic for black plaintiffs though it may be harder to detect.

\author{
(3) Hill v. Commonwealth: Another Illustration of the Impact \\ of the Social Meaning of Money on a Black Plaintiff's Tort Recovery
}

The Wright case is not totally unique in illustrating the role the social meaning of black people’s money may play in producing low verdicts for black plaintiffs. Hill $v$. Commonwealth $^{20}$ also seems to reflect the phenomenon. Plaintiff Hill was an inmate in a Pennsylvania prison. ${ }^{21}$ He fractured his ankle on a playing field as a result of the clear negligence of the Bureau of Corrections. He suffered severe pain at the time of the accident, following his first operation, and thereafter. ${ }^{22}$ His injury was permanent; he

jurors. See generally Frank M. McClellan, The Dark Side of Tort Reform: Searching for Racial Justice, 48 Rutgers L. Rev. 761 (1996). I have been told by practicing attorneys that sometimes a black plaintiff's address will give her/him away right at the outset of the litigation. At other times, the opposing side will adjust its valuation of a case downward after it has seen the plaintiff and heard her/him speak. Furthermore, black plaintiffs may be harmed not only by lower recoveries, but also by limitations placed on the use of damage awards and by the designation of selective sources of payout through such devices as joint and several liability. Id.

Of course, the social value of money is not the only explanation for the generally lower settlements and verdicts black personal injury plaintiffs recover. See generally Martha Chamallas, The Architecture of Bias: Deep Structures in Tort Law, 146 U. Pa. L. Rev. 463 (1998). Blacks’ out-of-pocket expenses or special damages may reflect the impact of employment discrimination which reduces their wage loss and shortens their work life expectancy. Income levels also affect the medical bills they incur and the amount of time they take off from work. Damages for more intangible harms like pain and suffering generally bear some relation to the special damages plaintiffs recover. Moreover, judges and jurors may find it difficult to understand the pain that blacks suffer from certain kinds of injuries or to quantify their suffering. Claims of discrimination, for example, may be undervalued and under-rewarded because discrimination seems ubiquitous and pervasive, whereas other forms of emotional distress seem unique and rare.

\footnotetext{
${ }^{20} 555$ A.2d 1362 (Pa. Commw. Ct. 1989).

${ }^{21}$ Id. at 1363.

${ }^{22}$ Id. at 1366.
} 


\section{Draft-Money Paper}

\section{Regina Austin - Penn Law}

May 15, 2012

developed tendinitis and arthritis and could no longer play strenuous sports. ${ }^{23} \mathrm{~A}$ panel of arbitrators awarded him $\$ 17,341.74 .{ }^{24}$ On appeal, however, a jury gave him a mere $\$ 1,800$ (or $30 \%$ of his special damages which totaled $\$ 5,844$ ) as compensation for his pain and suffering and permanent injury. ${ }^{25}$ There was no claim of contributory negligence, nor any basis for a compromise verdict. ${ }^{26}$ The plaintiff contended "that the only rational explanation for the jury’s low award [was] the jury’s prejudice against him as a convicted prisoner or as a black person or both.”27 The court responded that such a possibility could not be ruled out and awarded the plaintiff a new trial on the issue of damages. $^{28}$

Given who plaintiff was, where he was, how he probably got there, and what he could and should do with money in light of the forgoing, the jury in Hill may have concluded that he did not merit much monetary compensation for his pain and permanent disability, however great they may have been. His status as a prisoner undercut his general deservingness as a victim. Giving him a larger recovery might have seemed like a waste of money or an improper use of money. Hill was not really free to spend the money. Most of his immediate needs were being satisfied by the defendant, at least in the short run. The jury may have given little thought to recompensing Mr. Hill for his permanent or long-term suffering or found it hard to take the long view where a poor black prisoner was concerned. The fact that the defendant was an extension of the state and that the damages would have come from the public treasury to which the jurors very

${ }^{23}$ Id. at 1367.

${ }^{24}$ Id. at 1364.

${ }^{25}$ Id. at 1364, 1366.

${ }^{26} I d$. at 1365.

${ }^{27}$ Id. at 1368.

${ }^{28} I d$. 


\section{Draft-Money Paper}

\section{Regina Austin - Penn Law}

May 15, 2012

likely contributed, and the plaintiff very likely did not, may have made the jury reluctant to award him much in the way of damages. The jury may have taken the notion of a prisoner's owing a debt to society rather literally by imposing a sort of lien on Mr. Hill's recovery and reducing the amount it awarded. Operating on ordinary understandings regarding the social meaning of money, the jurors very likely viewed the money they were awarding in light of the full context and reduced the amount accordingly.

At this point, some of my readers might object to the attempt to attribute low jury verdicts to the significance attached to money in the hands of black plaintiffs as opposed to the discriminatory undervaluation of their out-of-pocket losses and pain and suffering. The value of money does not change, my readers might charge; rather, Wright and Hill demonstrate that we value some people and their injuries differently when we should not. Studies undertaken by the courts have indicated that jury determinations with regard to certain items of damages are impacted by gender bias. For example, women who suffer disfiguring injuries seem to recover more than men with comparable scars because physical appearance is thought to be more important in and to women than men. ${ }^{29}$ Conversely, women who are homemakers recover less for pain and suffering than men and women who work outside of the home because homemaking is considered less stressful. ${ }^{30}$ Racial bias may have a comparable effect. Medical doctors, studies have shown, often fail to deal adequately with minority patients’ pain, sometimes because the doctors underestimate its severity. ${ }^{31}$ Jurors may be guilty of the same kind of

${ }^{29}$ See, e.g., District of Columbia Courts, Final Report of the Task Force on Racial and Ethnic Bias and the Task Force on Gender Bias in the Courts 130(1992) (reporting the results of an attorney survey); Katherine Tamblyn \& David L. Wood, Final Report of the Colorado Supreme Court Task Force on Gender Bias in the Courts 104 (1990) (reporting the results of the task force survey).

${ }^{30}$ District of Columbia Courts, id. at 131.

${ }^{31}$ See Charles S. Cleeland et al., Pain and Treatment of Pain in Minority Patients with Cancer: The Eastern Cooperative Oncology Group Minority Outpatient Pain Study, 127 Annals Internal Med. 813 (1997). This study found that more minority patients were undermedicated 


\section{Draft-Money Paper}

\section{Regina Austin - Penn Law}

May 15, 2012

misfeasance. Real estate appraisers allegedly value the home of a person they believe to be black for less than they would if they thought that the homeowner was white. ${ }^{32}$ Jurors may similarly undervalue blacks’ property losses. When black plaintiffs wind up with less than their injuries seem worth or than comparably situated white plaintiffs would have recovered, it is their losses that are being devalued, my critics might claim, not the dollars in which the valuations are made and the damages, paid.

Discrimination cannot be curbed without understanding its complex machinations. Discrimination manifests itself in many ways; influencing the social meaning of money is

for their reported pain than white patients and that males whose physicians underestimated their pain were six times more likely to be undermedicated than those correctly diagnosed. The inadequate prescription of analgesics for minority patients might have been attributed to the difficulty physicians encounter in assessing pain in a patient who is from a different cultural background or who speaks a different language. Concerns about drug abuse and the adequacy of resources with which to pay for pain medicine may also have impacted the pain management decisions. See also Deborah Dillon McDonald, Gender and Ethnic Stereotyping and Narcotic Analgesic Administration, 17 Res. in Nursing \& Health 45, 48 (1994) (finding that minority postoperative appendectomy patients received significantly less medication than white patients; "[m]inority patients may have been either less likely to express their pain or more reluctant to receive narcotic analgesics, or their complaints may have been given less credibility); Knox Todd et al., Ethnicity as a Risk Factor for Inadequate Emergency Department Analgesia, 269 JAMA 1537 (1993) (reporting that Hispanic patients with bone fractures were twice as likely as whites to receive no pain medication; it was impossible to tell from the data, however, whether cultural differences affected the physicians’ ability to recognize patients’ pain).

${ }^{32}$ See Joseph N. Boyce, L.A. Riots and “The Black Tax,” Wall St. J., May 12, 1992, at A24 (recounting how the black writer’s Atlanta home was listed in the mid-\$80,000s, but was appraised in the low $\$ 70,000$ s when his wife and children were home, and then reappraised for $\$ 12,500$ more when his white secretary and her blond child were playing in the den and their pictures were prominently displayed around the house). Despite the passage of fair housing and equal credit opportunity laws, black home buyers have an increased likelihood of receiving low appraisals. See Michael LaCour-Little \& Richard K. Green, Are Minorities or Minority Neighborhoods More Likely to Get Low Appraisals?, 16 J. Real Estate Fin. \& Econ. 301, 31213 (1998). A low appraisal is one that is for less than the amount agreed upon in the contract of sale and may result in the denial of credit or the extension of credit on less favorable terms (higher down payment, mandatory mortgage insurance, etc.) than if the appraisal were equal to or higher than the agreed upon price. Id. at 301-02. See also Gregory D. Squires \& Sally O’Connor, Color and Money: Politics and Prospects for Community Reinvestment in Urban America 176 (2001). 


\section{Draft-Money Paper}

\section{Regina Austin - Penn Law}

May 15, 2012

one of them. There is something to be said for taking the Wright jurors at their word. They focused on the amount of money they should award the plaintiff given her assumed status as a former welfare recipient and profligate spender, not on the valuation of her losses. I would assert that calculating a loss in terms of dollars and cents inevitably involves making a qualitative evaluation not only of the harm done but also of the money that damages either replace or represent. Moreover, a social or normative assessment of the money for which damages are a substitute surely makes it easier to convert a qualitative assessment of the harm a plaintiff has suffered into a quantitative amount. More significantly, however, rejecting my critics’ arguments and focusing instead on the money, the bottom line, like the jurors in the Wright case did, challenges head on the liberal conceits that money, though evil, is absolutely essential; that little is to be gained from trying to understand it fully because it is beyond the comprehension of ordinary mortals; and that, in any event, it is so potent that it cannot be made to do the bidding of anyone but the rich and powerful. ${ }^{33}$ The failure to take money seriously by attacking these notions bears grave consequences for litigants like Mrs. Wright and Mr. Hill and it behooves us to recognize that.

In the next section, I want to explore further the concept of the social meaning of money and suggest that it may have special significance for black people in general, not just black plaintiffs.

\section{(4) A Brief Primer on the Social Meaning ofMoney}

\footnotetext{
${ }^{33}$ For a similar critique, see Ross Gittell \& J. Phillip Thompson, Making Social Capital Work: Social Capital and Community Economic Development in Social Capital and Poor Communities 115, 118 (Susan Saegert et al. eds., 2001). Professors Gittell and Thompson challenge "the long-standing view that market economies have an inherent and unalterable tendency to exploit the poor, undermine the environment, and exacerbate various inequalities." They reject the notion that "markets must always serve neutral or morally repugnant ends." In their view, the real objects of such anti-market criticism are the bourgeois social values most marketers pursue and the " 'mis-education' of citizens on the role of social ties and cooperative action in the economic process."
} 


\section{Draft-Money Paper}

\section{Regina Austin - Penn Law}

May 15, 2012

All dollar bills may look alike, but their value can vary widely. As Princeton sociologist Viviana Zelizer argues in her book, The Social Meaning of Money, ${ }^{34}$ money is not “absolutely fungible,” "qualitatively neutral,” "infinitely divisible,” or “entirely homogeneous." 35 Though, on the face of it, a dollar bill says little about where it has been and where it is headed, "people make every effort to embed money in particular times, places, and social relations." 36 The techniques for doing so include "restricting the uses of money, regulating modes of allocation, inventing rituals for its presentation, modifying its physical appearance, designating separate locations for particular monies, attaching special meanings to particular amounts, appointing proper users to handle specified monies, and earmarking appropriate sources of money for specified uses. ${ }^{37}$

Consider the myriad ways in which we describe or categorize money qua money to reflect its social significance, including the means by which the money was acquired, the ends to which it is put, and the quantity of money involved. ${ }^{38}$ Money earned by

${ }^{34}$ Zelizer, supra note $\underline{15}$.

${ }^{35}$ Id. at 10 .

${ }^{36}$ Id. at 18 .

${ }^{37}$ Id. at 29.

${ }^{38}$ Contra James Buchan, Frozen Desire: The Meaning of Money 18 (1997) (arguing that in the contemporary economy adjectives of quality that are applied to money only indicate "how much money is about.") 
employment, inheritance, or investment (“good money,”39 “serious money,"40 “old money," 41 or "smart money" "42) is distinguished from money obtained through criminal behavior ("blood money,”43 “dirty money,"44 or “hush money”45). By the same token, large sums of money that are the subject of sophisticated business transactions and macroeconomic monetary policy (“easy money,”46 “funny money,”"47 “hot money,”48 “soft

39 "Good money” is the salary paid by a "good job” or a substantial sum paid for a product or a service. Longman Dictionary of American English 519 (2d ed., 1997).

40 "Serious money" is a substantial salary. "Serious” in the black vernacular means “excellent or first-rate;” since the 1980's it has been generally used as "an all-purpose intensifier.” Jonathan Green, The Cassell Dictionary of Slang 1048 (1998).

41 "Old money" is "[i]nherited wealth, as distinct from that of the nouveaux riches." Dictionary of American Slang 400-01 (Robert L. Chapman, ed., 3d ed. 1995).

42 "Smart money" is "money ventured by a bettor or speculator likely to have inside information" or "investments by alert experienced investors." Once upon a time, the term referred to the money that soldiers or employees received for wounds and injuries and the sums paid to secure the release of a recruit from the military. Webster's Third New International Dictionary 2150 (Philip Babcock Gove et al. ed., 1993) [hereinafter Webster's Third]. In the law, “smart-money” is punitive or exemplary damages. Black's Law Dictionary 1246 (5 ${ }^{\text {th }}$ ed., 1979).

43 "Blood money" is money "obtained as the price or at the cost of another's life or sometimes of his happiness, good name, or welfare;" it is also "money received for betraying a fugitive or for committing murder, or . . . the price obtained for the sale of something that will destroy the purchaser. $I d$. at 237. The term also refers to "money paid directly to plaintiffs by defendants out of their own pockets, see Tom Baker, Blood Money, New Money, and the Moral Economy of Tort Law in Action, 35 Law \& Soc'y Rev. 275, 276 (2001), and the money paid by commercial blood banks to donors. See Joseph D. Diaz, Blood Money: Life, Death, and Plasma on the Las Vegas Strip, 4 Electronic J. Soc., Apr. 1999, at http://www.sociology.org./content/ vol004.002/diaz.html.

44 "Dirty money” is "obtained through dishonest, corrupt, or inhumane dealing."

Webster's Third, supra note $\underline{42}$, at 647.

45 “Hush money” is a blackmail payment. A Dictionary of Slang and Unconventional English 585 (P. Beale ed., 8th ed. 1984) [hereinafter A Dictionary of Slang].

46 “Easy money,” also known as “loose money,” is created when the Federal Reserve reduces interest rates and expands the amount of available credit which allows borrowers to 


\section{Draft-Money Paper}

\section{Regina Austin - Penn Law}

May 15, 2012

money,"49 "sound money," "50 and "tight money"51) are distinguished from the insignificant, even trivialized sums associated with the monetary affairs of dependent

obtain money more cheaply. Susan Lee, Susan Lee’s ABZ’s of Economics 68 (1987). In addition, "easy money" is "money obtained without especial hardship or effort; often money ... obtained unfairly and improperly (as by trickery or crime).” Webster's Third, supra note $\underline{42}$, at 717.

47 “Funny money” is either inflated currency, Webster's Third, supra note $\underline{42}$, at 923, or counterfeit currency. A Dictionary of Slang, supra note $\underline{45}$, at 437.

48 "Hot money” is "money of foreign ownership deposited or invested to avoid depreciation and constituting a threat to national currency and credit by being liable to sudden withdrawal-- called also funk money."’ Webster's Third, supra note $\underline{42}$, at 1095.

49 “Soft money" is (1) highly inflated currency; (2) money from research grants or other sources that are available for a fixed term or are nonrenewable; or (3) campaign contributions that are not subject to regulation by the Federal Election Commission. Dictionary of American Slang, supra note $\underline{45}$, at 317-18. This third usage was frequently invoked in connection with the fund-raising practices of the Clinton White House.

50 "Sound money" is "money not liable to sudden appreciation or depreciation in value; . . . especially a currency based on or redeemable in gold.” Webster's Third, supra note $\underline{42}$, at 2177.

51 “Tight money” is the antithesis of loose money. It results when the Federal Reserve clamps down on the supply of money by causing interest rates to rise, and thereby making borrowing less attractive. Lee, supra note $\underline{46}$, at 209. 


\section{Draft-Money Paper}

\section{Regina Austin - Penn Law}

May 15, 2012

women and children (“mad money,"52 “pin money,"53 “pocket money,"54 and "spending money"55).

The meaning of a descriptive term for money may vary with the context of social relations involved. For example, "play money” may refer to the imitation coins and bills used in board games, ${ }^{56}$ the constantly redesigned $\$ 50, \$ 20, \$ 10$ and $\$ 5$ bills, ${ }^{57}$ or sums invested in retirement plans that will not come into the investor's actual possession until she or he retires. Of course, this last sort of "play money” is a product of the laws that

52 "Mad money" is "the carfare carried by a girl on a date to provide a means of escaping her escort in the event of unwanted familiarities; broadly: a small sum carried by a woman for emergency use.” Webster's Third, supra note $\underline{42}$, at 1357. Money saved for splurging on a vacation or special occasion is also known as "mad money." A Dictionary of Slang, supra note $\underline{45}$, at 712 .

53 "Pin money" is "money allotted by a man to his wife, daughter, or sister for her personal expenses, esp. for clothes;" or "money used or set aside for the purchase of incidentals;” or "a trifling sum of money.” Webster's Third, supra note $\underline{42}$, at 1720. The earmarking of household money has varied over time along with changes in domestic social relations, particularly changes in the status of women in the family. See generally Viviana A. Zelizer, The Proliferation of Currencies, in The Laws of Markets 58, 60-65 (Michael Callon ed., 1998).

54 "Pocket money" is "money for small current personal expenses." Webster's Third, supra note $\underline{42}$, at 174. Pocket money is sometimes called “spending money.” Id. at 2190.

${ }^{55} I d$.

${ }^{56}$ Id. at 1737.

${ }^{57}$ See, e.g, Adam Gopnik, Metamoney, The New Yorker, Nov. 9, 1998, at 94. Gopnik writes that the new bills look cheaper than the old ones. Devoid of Gilded Age flourishes, bearing larger, off-center pictures of dead presidents, and revealing a hidden portrait and wording when the bills are held up to the light, the new money seems to be critiquing the old. Id. at 96. Says Gopnik, "The New Money comes to us at a time when money, the kind you put in your pocket, no longer makes the world go round. Cash is now the closest thing we have to contraband. ... Only those among us who are still deceived go to cash machines, thinking, Hey, we're in the money!” Id. at 98.

Computers and the internet are apparently making it easier to counterfeit money. The government is accordingly redesigning the bills to make them less susceptible to counterfeiting. See Maria Gold, Bogus Dollars from Internet Bring Change, Wash. Post, Mar. 20, 2002, at B1. 


\section{Draft-Money Paper}

\section{Regina Austin - Penn Law}

May 15, 2012

shelter retirement investments from immediate taxation and the economic forces that create the excess income which enables some of us to engage in long-range financial planning. Indeed, law and macroeconomics often play a role in shaping the social meaning of money.

Slang terms for currency --like "scratch,” "bread,” and “molla”-- may be the best illustration of the way in which people attempt to connect money with a particular time, place, and social milieu. ${ }^{58}$ Many of these terms are the product of deviant or marginalized subcultures that speak in code in order to avoid being understood by outsiders. Few outside of the young black hip hop generation and their followers probably know that “scrilla,” “cheese,” “cheddar,” and “papes”59 were terms for money which were totally passe before the rest of us could catch on.

In the endeavor to exert social control over the utilization of money, we even create different kinds of money. Although ours is basically a money-based economy as opposed to one based on barter or commodity exchange, many of us receive at least some of our compensation in the form of commodities or in-kind payments that are not easily translated into cash. In this regard, stock options and SNAP (Supplemental Nutrition Assistance Program) benefits, formerly known as food stamps, have something in common. Of course, there is a world of difference between stock options and SNAP benefits in terms of the socioeconomic status of the holder. SNAP benefits, which are the equivalent of a special purpose currency, are, like TANF (Temporary Assistance for Needy Families) or welfare benefits, identified with poor women, a class whose consumption preferences have long been subject to public control and scrutiny. Stock

${ }^{58}$ See also Leonard R. N. Ashley, You Pays Yer Money and You Takes Yer Choice: British Slang for Pounds and Pennies, Old and New, 21 Names: J. Am. Names Soc. 1 (1973) (cataloguing British slang for money).

\section{English 86 (2000).}

${ }^{59}$ John Russell Rickford \& Russell John Rickford, Spoken Soul: The Story of Black 


\section{Draft-Money Paper}

\section{Regina Austin - Penn Law}

May 15, 2012

options, on the other hand, are associated with high-level, highly-paid (some would say overpaid) corporate executives.

The social valuation of money is enforced in a way that resembles appropriation, or an exertion of ownership over other people's property. Our money economy does not carry with it a general acceptance of the freedom of anyone to use her/his money to pursue her/his own selfish or frivolous desires without risking social censure. ${ }^{60}$ As Zelizer suggests, “people will in fact respond with anger, shock, or ridicule to the 'misuse' of monies for the wrong circumstances or social relations, such as offering a thousand-dollar bill to pay for a newspaper or tipping a restaurant's owner.”61 Social rank affects one's entitlement to judge the expenditures of others and the likelihood that one's expenditures will be judged. Bourgeois norms especially demand the policing of others' desires, particularly as they are materially manifested through their expenditures. Whereas the wealthy are assumed to come by their money through impersonal means, the poor are required to prove their personal entitlement to money and are subject to a policing of their expenditures that is both personalized and paternalistic.

Theories regarding the social meaning or value of money have intriguing implications insofar as racial and ethnic minorities are concerned. As the discussion thus far has suggested, money is at base a social and cultural artifact. Where there is more than one culture occupying the same social landscape, there is the potential for cultural conflict. This is certainly true with regard to money. People of different races, ethnicities, and nationalities attach different significance to money and its uses. Those differences are reflected in folk lore, aphorisms, ceremonies, popular culture, and popular

${ }^{60}$ Contra Buchan, supra note $\underline{38}$, at 20 (arguing that by participating in the money economy we accept the freedom of other participants "to choose their frivolity and selfishness, their universal subjection to desire, their humanity.”)

${ }^{61}$ Zelizer, supra note $\underline{15}$, at 19. 


\section{Draft-Money Paper}

\section{Regina Austin - Penn Law}

May 15, 2012

opinion, not to mention the economic behavior of a group. ${ }^{62}$ At the same time, however, other people's money is the stuff of stereotypes and slurs. It is widely assumed that there is such a thing as "Cuban-American money” or "Jewish money." In stereotypical thinking, "Jewish money” is the product of avarice and greed. It is the money Jews use to buy influence or the money they acquire by grubbing or through sharp money practices. ${ }^{63}$ "Jewish money" to Jews is something entirely different. It is a defense against anti-

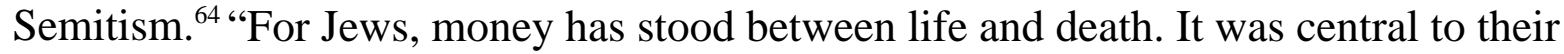
existence. ... . Without their financial usefulness, they would have been obliterated long ago.” ${ }^{65}$ However, Jewish values regarding money and economic success, upon analysis, are not that different from those of other groups that are identified with self-denial, hard work, and social and professional advancement. ${ }^{66}$ But even this more affirmative assessment of “Jewish money” may be the stuff of anti-Jewish stereotypes. ${ }^{67}$

The subject of racial and ethnic monies requires a writer or speaker to negotiate gingerly a minefield of stereotypes and cultural soft spots or sore points. Moreover, the full legal implications of what are clearly perceived as distinctive racial and ethnic

${ }^{62}$ See generally Kenneth O. Doyle \& MacKenzie R. Doyle, Meanings of Wealth in European and Chinese Fairy Tales, 45 Am. Behav. Sci. 191 (2001); Göran Stockenström, Swedish Myths about Money, 45 Am. Behav. Sci. 240 (2001); Giovanna Dell'Orto \& Kenneth O. Doyle, Poveri Ma Belli: Meanings of Money in Italy and in Switzerland, 45 Am. Behav. Sci. 257 (2001) (asserting that for Italians money is to be earned through hard work and then generously spent, while for the Swiss money is to be earned through mental labor and saved).

${ }^{63}$ See Gerald Krefetz, Jews and Money: The Myths and the Reality ix-x (1982).

${ }^{64} I d$. at 246.

${ }^{65} \mathrm{Id}$. at 5.

${ }^{66} \mathrm{Id}$. at $39-40$.

${ }^{67}$ See Thomas C. Wilson, Compliments Will Get You Nowhere: Benign Stereotypes, Prejudice and Anti-Semitism, 37 Soc. Q. 465 (1996) (reporting results of an empirical study that suggests that benign Jewish stereotypes mask underlying prejudice or may be held in conjunction with blatantly anti-Semitic stereotypes). 


\section{Draft-Money Paper}

\section{Regina Austin - Penn Law}

May 15, 2012

monies are a matter deserving of much greater attention than can be devoted to it in the course of this Essay. The matter is raised only to support the viability of the questions that I have undertaken to analyze here, namely: Is there such as a thing as "black people’s money?” If so, is it worth the same as “white people’s money?” In other words, does the social and cultural value of black people's money, assuming that it exists, affect its economic or material worth? These conundrums lie at the intersection of law, economics, and culture like no other. Though the meaning and value of black people's money is a difficult subject to broach, it must be addressed on some level, however tentatively, because of its significance to claimants like Mrs. Wright and Mr. Hill. In the discussion that follows I hope to show that who possesses money, how they acquired it, what they will spend it on, where they will spend it, and why are all relevant not only to its social value, but also to its ultimate value, i.e., its material clout or utility in our socalled "free market" economy.

\section{(5) Postulating the Existence of "Black People’s Money"}

Admittedly, it is very hard to conceive of black people's money (or money in the hands of or circulating among black people if these are easier concepts to grasp) as being different in any way from other people’s money. There are so many familiar proverbs and pithy sayings in our multi-racial/multi-cultural society that convey the message that money is blind to race, gender, and class distinctions: "Money. You don’t know where it's been, but you put it where your mouth is. And it talks."68 "The universal color is green.”69 "With money in your pocket, you are wise and you are handsome and you sing

\footnotetext{
${ }^{68}$ The Oxford Book of Money 3 (Kevin Jackson ed., 1995) (quoting Dana Gioia, The Lions of Winter, 1991).

${ }^{69}$ The phrase is a contemporary expression of the power of money to overcome racism. For example, it was used in two news articles dealing with black economic progress. See Tom Beyerlein \& Ken McCall, Minorities' Homeownership Gains, Lags: Rate Soars for Whites, but Not for Blacks, Dayton Daily News, July 15, 2001, at 1A (quoting a loan officer who touts the use of a mathematical formula that reportedly removes bias from determinations of borrower creditworthiness); Allan Sloane, A Starring Role in Black Entertainment TV's Horatio Alger
} 


\section{Draft-Money Paper}

\section{Regina Austin - Penn Law}

May 15, 2012

well too.”70 "Flea has money he buys his own dog."71 Money supposedly narrows or closes the more than arms-length distance that separates customers and merchants, buyers and sellers, and those who possess money and those who desire to possess it, where the former in each dyad comes from a much lower station in life. Money has been said to create the possibility of "purely purposeful” associations in which individuals can maintain their distinct identities and interact with people who are radically different from themselves. ${ }^{72}$ Nonetheless, the reality is that black people's money, relative to white people's money, is, in some but not all contexts, like a South African rand, a Cuban peso, or an Indian rupee, i.e., a different kind of currency for which there are (implicit) rates of conversion or exchange. Coarse, simplistic economic modeling illustrates how this is possible.

Though it looks no different from white people’s money, black people’s money is “marked” as different in various ways. With regard to many goods and services, blacks buy and sell in different markets that are segmented or walled off and distinct from the markets of the white mainstream. In addition, blacks’ identities are generally self-evident to the parties with whom they contract; their race may be discernable from their appearances, their names, their addresses (especially zip codes), their accents, and their patterns of speech. This creates the possibility for commercial interactions that are subject to distinct practices, norms or assumptions, strategic behavior, and ultimately

Story, Wash. Post, Oct. 1, 1991, at D3 (invoking the saying in the context of a description of the estimated $\$ 100$ million initial public stock offering of BET, a concern its black founder started with a loan of $\$ 15,000)$.

${ }^{70}$ The Whole World Book of Quotations: Wisdom from Women and Men Around the Globe Throughout the Centuries 185 (Kathryn Petras \& Ross Petras eds., 1995) (quoting a Yiddish proverb).

${ }^{71}$ Walter B. Hoard, Anthology: Quotations and Sayings of People of Color 128 (1973) (quoting a Jamaican proverb).

${ }^{72}$ Nicholas J. Spykman, The Social Theory of Georg Simmel 231 (1965). 


\section{Draft-Money Paper}

Regina Austin - Penn Law

May 15, 2012

outcomes, particularly where blacks lack information about comparable transactions involving whites. ${ }^{73}$ Thus, black people's money is socially constructed by the mechanisms which restrict blacks' transactions to certain times, places, and virtualspaces as well as to face-to-face encounters or their equivalents.

Like any other distinct currency, the value of black people's money is not divorced from the value of what can be bought and sold with it. Where the price of an item (be it a car, a house, or pain and suffering) is not fixed but is negotiated or flexible, the sum agreed upon by the parties will depend on the value of the item being purchased or sold and the value of the currencies in which the negotiating parties do business. The value of one currency (think U.S.\$) relative to another (think European euro or $€$ ) roughly speaking depends on what it can be used to buy or what it will otherwise earn if invested. Thus, the value of a country's money varies with the expected aggregate price level of its goods, services, and assets ("commodities”); the tariffs and quotas it imposes on competing imports; interest rates; consumer preferences; and changes in the level of productivity. ${ }^{74}$ If the price of a country's commodities, its interest rates, its tariffs or quotas, the demand for its exports, or its productivity rises, the value of its currency will rise too. That will increase the exchange rate and it will take more of the currency of

${ }^{73}$ See generally Ian Ayres, Pervasive Prejudice?: Unconventional Evidence of Race and Gender Discrimination 19-162 (2001) (reporting the results of empirical studies involving structured bargaining over the purchase price of a car in which black testers wound up with much worse deals than white male testers). Ayres attributes the racial disparity in the prices agreed on in part to automobiles being “credence goods.” Id. at 11, 161-62. A credence good is one whose characteristics the consumer must take on faith because they cannot be verified by the consumer's individual experiences. Id. at 11, 162. If black customers do not know how white customers are treated at the time of sale and cannot garner such information in the course of consuming the product, then equality of treatment is a credence attribute and the product is a credence good with regard to it. Id. at 11.

${ }^{74}$ See Fredrick S. Mishkin, The Economics of Money, Banking, and Financial Markets 185-191, 200-10 (6th ed. 2001); R. Glenn Hubbard, Money, the Financial System, and the Economy 155-59, 168-73 (3d ed. 2000). 


\section{Draft-Money Paper}

\section{Regina Austin - Penn Law}

May 15, 2012

other countries to buy the former's commodities. ${ }^{75}$ Conversely, it will take less of the money of the country with the rising indicators to buy the commodities of other countries because the former country’s currency will have more purchasing clout relative to the currencies of the latter.

Much the same process affects the value of black people’s money (think $€$ ) relative to white people's money (think $\$$ ) and in turn the terms of transactions in which black people’s money figures. ${ }^{76}$ Posit that blacks and whites share common assumptions about the value of black people’s money. If blacks are buying goods, services, or assets in white markets, the value of their marked currency is clearly in issue. If black people's money is worth less, a white seller will demand more and hold out longer than if she/he were dealing with a white buyer paying with white people’s money. The black buyer, likewise, will expect to pay more or realize that paying less will entail the expenditure of higher bargaining costs which may ultimately prove misspent. The convergence of these two approaches will result in blacks' paying a higher price than whites for comparable goods and services. ${ }^{77}$ Consider further the negative impact on the investment potential of black people's money of the lower level of black entrepreneurship and economic development. If the commodity being purchased is money (i.e., credit) to be invested in

${ }^{75}$ Mishkin, supra note $\underline{74}$, at 168-70.

${ }^{76}$ During the summer of 2002, the euro achieved parity with the dollar. See Steven Erlanger, Euro Edges Past the Dollar in a Victory for Europeans, N.Y. Times, July 16, 2002, at C1. The euro is now worth $\$ 1.32$.

${ }^{77}$ In his study of automobile price negotiations, Professor Ayres found that black males were thought to have the highest reservation prices (or maximum offer) of the four categories of consumers (i.e., higher than white males or females or black females). Ayres, supra note $\underline{73}$, at 77. Dealers bargained longer with and made smaller concessions to black males. This behavior, according to Ayres, suggests that white dealers attached a higher value to, or reaped greater enjoyment from, extracting profits from black males than others. Id. at 68-69. Black women, on the other hand, had the highest bargaining costs. "Higher bargaining costs tend to reduce one's bargaining power.” Id. at 59. Sellers take advantage of this by making fewer concessions; as a result, the constrained buyer pays more. Id. at 54 . 


\section{Draft-Money Paper}

\section{Regina Austin - Penn Law}

May 15, 2012

black markets, the lower return that can be reaped there will drive up the cost of borrowing and the transaction will proceed on less favorable terms than if the borrower were white. Finally, because of the more limited use to which black people's money can be put within black markets, some blacks have little choice but to seek profit making opportunities outside of such markets on terms that are likely to favor white sellers. Each of these possibilities would make a black buyer's money worth less and adversely impact the cost of the black buyer's deal with a white seller. Each is consistent with the common assumption held by blacks that they bear the burden of an (implicit) across-the-board tariff or so-called "black tax" on the privilege of transacting business in white markets. ${ }^{78}$

Where blacks are selling commodities to whites, the impact of the value of black people's money on the transaction is more convoluted, but no less profound. A white

${ }^{78}$ See Boyce, supra note $\underline{32}$, at A24 (defining "the black tax" as "the additional price in dollars one pays as a victim of racial discrimination”). See also Jody David Armour, Negrophobia and Reasonable Racism: The Hidden Costs of Being Black in America 14 (1997) (using the term "black tax to refer to the material and nonmaterial price blacks pay on account of racial stereotypes;" discrimination is likened to a tax because both are "persistent," “pervasive,” unavoidable, "not generally resisted," and exacted by or through agents of the state). The metaphor of the black tax capitalizes on general anti-tax sentiments to build a community of resistance to discrimination among black people. Carolyn C. Jones, Mapping Tax Narratives, 73 Tul. L. Rev. 653, 690-94 (1998).

Some folks have so come to believe in the existence of the black tax that they have been victimized by con artists promising to assist black taxpayers to secure credits for or refunds of the improperly imposed levy. Id. at 691-92. Contemporary efforts to secure reparations for black enslavement have increased the incidence of "black tax" scams. See Ernie Suggs, Officials: "Black Tax" Scam Preys on the Elderly, Atlanta J.-Const., Apr. 8, 2001, at B2 (reporting on scams that elicit payments of \$50 to \$500 and personal data like social security numbers from elderly blacks convinced of their entitlement to a tax credit as slave reparations); Michelle Singletary, Reparations: A Tax Con with a History, Wash. Post, Mar. 4, 2001, at H1 (suggesting that the appeal of a tax credit as a form of slave reparations is based on history and the interest in reparations voiced by contemporary black leaders and legal authorities); Tatsha Robertson, Reparations Pitch Draws Hope, Scorn, Boston Globe, Oct. 17, 2000, at A1 (describing the activities of a reparations advocate who in addition to misinforming black church members about the existence of a black tax rebate also collects fees to file reparations claims with the government); Russell Ben-Ali, Scam Promises Blacks Reparations for Slavery, StarLedger (Newark, NJ), Oct. 12, 2000, at 15 (describing how unethical tax preparers use IRS capital gains Form 2439 to bilk blacks interested in obtaining a "black tax” refund). 


\section{Draft-Money Paper}

\section{Regina Austin - Penn Law}

May 15, 2012

buyer may adopt either or both of two negotiating strategies. The white buyer may assume that, because of discrimination, anything a black person has to sell is worth less than if a white person were selling it. The depressed prices of goods, services, and assets circulating in black people's markets are, at least in part, due to the reduced value or purchasing power of black people's money. There are fewer buyers for black properties simply because there are fewer black people than white people. Blacks do not have as much money as whites and are unable to obtain credit on the same terms as whites. The quantity and the quality of the money at blacks' disposal thus impact negatively on the value of black property. For example, the homes of blacks have not appreciated to the same extent as comparable white properties. ${ }^{79}$ Equally as important, the reverse is true; that is, the value of black property depresses the value of black people's money which depends in part on what blacks can buy with it.

In addition, a white buyer entering a black market with white money, a stronger currency, is in an advantageous position. Whatever the value of the property, the white buyer should negotiate so as to get the full benefit of her/his money's worth. A white person could achieve a lower price if she/he hired a black straw to do the negotiating for her or him; this would be the equivalent of converting her/his white money into black money and then making the purchase. Black straws or buying agents are probably easier to find than white ones. The negotiations between the white buyer and the black seller will be conducted as if a black straw were actually involved.

These arguments are not meant to be wholly accurate descriptions of the way in which black/nonblack commercial transactions invariably work. They do suffice to illustrate, however, that money has no more intrinsic value than any other commodity or, more precisely, that money's value can be impacted by the pernicious effect of racism and ethnocentrism. In a great many situations, the real value of money cannot be determined

\footnotetext{
${ }^{79}$ Melvin L. Oliver \& Thomas M. Shapiro, Black Wealth/White Wealth: A New Perspective on Racial Inequality 147-51 (1995).
} 


\section{Draft-Money Paper}

\section{Regina Austin - Penn Law}

May 15, 2012

without reference to the cultural and social capital of its possessor. ${ }^{80}$ Very often, "what can be achieved with money” depends on “pre-existing networks of relationships” and “degrees of access to ... goods and services not accounted for by the price

${ }^{80}$ As used in this Essay, social and cultural capital have meanings largely drawn from Pierre Bourdieu, Distinction: A Social Critique of the Judgement of Taste 169-75 (Richard Nice trans., 1984). Cultural capital includes habits of style, taste, manners, social competence or confidence, and self-assurance, as well as the institutional mechanisms to define and legitimate the values and standards on which all sorts of qualitative assessments of social distinction are drawn. Cultural capital is produced by socialization and education. For example, the cultural capital imparted to the children of the petite bourgeoisie includes an understanding and appreciation of the values and practices of entrepreneurship and money management. This gives the offspring of the petite bourgeoisie the tools with which the class can reproduce itself. Id. at 92-94. Unlike human capital which rather directly increases one’s productivity, cultural capital's relationship to economic well-being is more attenuated. Cultural capital generates prestige and recognition which can lead to advantageous jobs, marriages, and business contacts which in turn can translate into material wealth, though not necessarily. See Ivan Light \& Steven J. Gold, Ethnic Economies 91 (2000).

Social capital, on the other hand, is "a capital of social connections, honourability and respectability." Bourdieu, supra, at 122. It is created by social networks and ties produced and sustained by exchanges, mutual obligations, and shared identities that in essence pay off in terms of support and access to resources. Denoting the web of connections, loyalties, and mutual obligations (shared fate, solidarity, and communal membership) that develop among people as part of their regular interaction, social capital refers to the sense of commitment that induces people to extend favors, expect preferential treatment, and look out for one another's interests." Id. at 110.

It should be noted that social capital is a much debated and contentious concept in the social sciences. See, e.g., Alejandro Portes, Social Capital: Its Origins and Application in Modern Sociology, 24 Annual Rev. Soc.1 (1998) (reviewing the spectrum of writing on the subject). Portes argues that the negative consequences of social capital are often overlooked. Id. at 15-18. "Social ties can bring about greater control over wayward behavior and provide privileged access to resources; they can also restrict individual freedoms and bar outsiders from gaining access to the same resources through particularistic preference.” Id. at 21. Moreover, groups, in addition to individuals, may possess social capital. Id. at 18-21. Racial/ethnic and feminist solidarity or group identification are forms of group social capital. According to Portes, however, there is a tendency on the part of some scholars to view social capital as a panacea that will cure the ills of unorganized poor and socially or politically marginalized communities. Social capital may be evidence of the existence of civic virtue and social integration in a community and not their cause. Id. at 19-21. 


\section{Draft-Money Paper}

\section{Regina Austin - Penn Law}

May 15, 2012

mechanism.” ${ }^{81}$ For example, “[p]rice may not be the sole determinant of access to art, property and the services of others. [Moreover, the] capacity to pay is rarely the sole determinant of access to credit for individuals, firms, and governments.” Hence, money’s worth is open to conjecture and speculation all of the time. We believe otherwise because we simply refuse to see that money is something created by us (i.e., people) and therefore its value is socially contingent and contested.

Money is an expression of social power and a mechanism for reproducing and disrupting the social hierarchy. The jurors in the Wright case recognized that; they were intent on reproducing the economic status quo, if not altering it more in favor of their own class position. But monetary transactions can be used not only to "create, define, affirm, and represent ... [ [our] social ties," but also to "challenge” and “overturn” them. ${ }^{82}$ Money is an instrument of social struggle, and social struggle is an integral component of what money is and can do. Thus, exploring the impact of race and ethnocentrism on money’s value entails consideration of group conflict. ${ }^{83}$

It follows from these conclusions that assessments of harm or injury cannot be divorced from the value of the currency in which the harm or injury will be recompensed. Both the value of the thing appraised and the value of the currency in which the appraisal is made are the historically contingent product of antagonistic social relations between the valuers, the payers, and the persons whose worth, wounds, and wealth are being measured. When white jurors value a claim of harm done and award money damages to a black plaintiff, they are constructing social relations around money at the same time that they are making a symbolic statement about justice, loss, and race relations, and

\footnotetext{
${ }^{81}$ Nigel Dodd, The Sociology of Money: Economics, Reason and Contemporary Society 160 (1994).

${ }^{82}$ Viviana A. Zelizer, Introduction: How People Talk About Money, 41 Am. Behav. Sci. 1371, 1378 (1998).

${ }^{83}$ Geoffrey Ingram, On the Underdevelopment of the Sociology of Money, 41 Acta Sociologica 3, 14 (1998).
} 


\section{Draft-Money Paper}

\section{Regina Austin - Penn Law}

May 15, 2012

distributing or redistributing economic wealth, sometimes from the poor to the rich.

Thus far I have posited that black people's money is generally worth less than white people's money. Exchange rates for the two currencies, however, are not listed in the financial pages of major newspapers or displayed on billboards in banks and currency exchange outlets. How then are these currencies valued relative to each other and how are the exchange rates maintained? I would argue that the general societal or cultural devaluation of black people's money operates just as effectively as posted exchange rates to reduce its value. The next section considers the economic stereotypes and widely shared cultural understandings that do the trick of lowering the value of black people's money, though not without contestation.

\section{(6) Insuring That Black People’s Money Is WorthLess}

\section{Through the Cash/Crime Nexus}

It is my hypothesis that the value differential between black people's money and white people's money is maintained by the tendency to treat black money as if it were a fetish subject to a taboo. Black people’s money or "black money" is worth less because it is treated as if it were a sacred object that has fallen into the wrong hands, lost its magical power, and become tainted and devalued in the process. The denigration of black economic activity attaches itself to currency in black hands so as to debase or belittle it. The money figuratively becomes black until it is returned to white hands (or the equivalent), at which point its full potency is restored. The black money fetish/taboo leads some whites, some nonblacks, and even some blacks to feel entitled to bargain blacks out of the full purchasing power of their money or to relieve them of their money by fraud and slick business practices without fearing a great deal of social censure. It likewise leaves some blacks more vulnerable to being outbargained or outright ripped off because they too accept the idea that money is worth less in their hands.

The idea that money is a fetish is a common one. A fetish is an object, regarded as sacred or magical, to which a people are devoted, irrationally or obsessively so from the 


\section{Draft-Money Paper}

\section{Regina Austin - Penn Law}

May 15, 2012

point of view of those outside of the culture. ${ }^{84}$ Marx teaches us that our money is fetishized or constructed as a thing or a commodity that is inherently valuable so as to conceal or disguise the class relations (e.g., the relations between capitalists and workers) that actually produced the material wealth it represents. ${ }^{85}$ As the theory of the social meaning of money suggests, however, people go to great lengths to embed other social relations in money and to confer on it a social or cultural value in addition to any other value it might symbolize. Marx’s denuded, fetishized money is re-fetishized, in the anthropological sense, through cultural practices that promote the social distinction or stratification of money’s possessors on any number of plains. (Of course, the class relations that actually produce money or material wealth are no less obscured thereby than Marx posited them to be.)

For example, according to Victorian notions that remain alive still, money is at its most sacred when it is in the possession of those who exhibit thrift, diligence, energy, civility, a sense of history, and a touch of the class or cultural capital that a great deal of money can buy. ${ }^{86}$ There are other people in whose hands money should not want to be found, i.e., people who give even money a bad name. They are generally people who come by their money in less than honorable ways or who do not know what to do with it. Thieves, slackers, misers, the gauche, and the profligate most certainly fall into this category. Corporate fat cats, women, minorities, and the poor probably do as well. As

${ }^{84}$ Tim Dant, Fetishism and the Social Value of Objects, 44 Soc. Rev. 495, 496, 499 (1996) (stressing that labeling an object a "fetish" is a form of cultural criticism in that it identifies “someone else’s reality as an illusion”).

${ }^{85}$ Karl Marx, Capital: A Critique of Political Economy 168-69 (Ben Fowkes trans., First Vintage Books 1977) (1906).

${ }^{86}$ See Lendol Calder, Financing the American Dream: A Cultural History of Consumer Credit 87-91 (1999) (describing the Victorian ethic of money management). 


\section{Draft-Money Paper}

\section{Regina Austin - Penn Law}

May 15, 2012

with a taboo, ${ }^{87}$ it is sacrilegious or dangerous for members of these groups to possess an inordinate amount of money, the sacred object, and entirely justified for them to be relieved of it expeditiously, whether by artifice or legitimate means, so that it can be purified and returned to the realm of the sacred.

Black people's money is fetishized in this way along with that of other subordinate groups, but there is more operating in the case of blacks. Fetishization also works to associate black people's money with the least important and sophisticated of the different kinds of money in a way that exposes all of their money to being devalued.

Money is anything that serves as (1) a medium of exchange or a means of payment that is widely accepted, (2) a unit of account used to measure value, and (3) a store of value or purchasing power that lasts over time. ${ }^{88}$ So defined, there are many different kinds of money or money substitutes flowing throughout the "multi-tiered” American payments system. ${ }^{89}$ There are (1) conventional physical money (paper currency and coins or cash); (2) near currency substitutes (checks, travelers’ checks, food stamps); (3) money that travels via electronic funds (wire) transfers (bank and travel \& entertainment credit cards, debit cards, ATM or cash machine cards); and (4) electronic money which resides in computer memory and may or may not have a corporeal existence (stored-value and smart cards, cybermoney or electronic cash, and electronic checks). ${ }^{90}$ The more sophisticated the form of money, the faster and farther it travels across time and space, the

${ }^{87}$ A taboo is "a ritually sanctioned prohibition against contact with a thing, a person, or an activity.” The Dictionary of Anthropology 464 (Thomas Barfield ed., 1997).

${ }^{88}$ Mishkin, supra note $\underline{74}$, at 49-52; Hubbard, supra at note $\underline{74}$, at 16-21.

89 Jack Weatherford, The History of Money 230 (1997).

${ }^{90}$ Mishkin, supra note 74, at 52-57; Hubbard, supra note 74, at 21-24; Elinor Harris Solomon, Virtual Money: Understanding the Power and Risks of Money's High-speed Journey into Electronic Space (1997). 


\section{Draft-Money Paper}

\section{Regina Austin - Penn Law}

May 15, 2012

larger the amounts involved, and the more impersonal the transactions actually are. ${ }^{91}$

There are other social differences among the categories of money. The form of money in which an individual or group commonly conducts commercial transactions both reflects and constructs her/his/its social standing, as well as reflects the social value or clout of her/his/its money. The lower the economic wealth or earnings of a person or group, the more primitive the form of money in which she/he/it typically transacts business and the more expensive those transactions are. ${ }^{92}$

As I argue elsewhere, black people’s money in general, whatever forms it actually takes, is associated with cash. ${ }^{93}$ When we think of cash, we envision small amounts of money that will fit into a wallet or large amounts of money illegally obtained or unwisely accumulated. Cash is the least sophisticated, least efficient, and least productive form of money. Cash is not capital. Cash is meant to be spent or put in the bank; it is largely a tool of consumption, not an instrument of investment. If one has money and does not know what to do with it, it might as well be cash. Moreover, cash fuels the informal economy of unregulated, off-the-books self-employment and small-scale enterprise and the criminal underground economy of drug dealing, fencing, loan sharking, racketeering, and prostitution. The requirement that cash transactions of $\$ 10,000$ or more be reported to the Treasury Department has burned into the popular imagination the tie between cash

\section{${ }^{91}$ Andrew Leyshon \& Nigel Thrift, Money Space: Geographies of Monetary Transformation 22 (1997); Keith Hart, The Memory Bank: Money in an Unequal World 5-} 6 (2000).

${ }^{92}$ Weatherford, supra note $\underline{\text { 89}}$, at 249 \& 211. See generally Jan Pahl, Invisible Money: Family Finances in the Electronic Economy (1999) (reporting on the results of a qualitative study involving thousands of British families which revealed that the form of money used (cash, cheques, credit cards, debit cards, smart cards, loyalty cards) by family members varied with gender, income, and employment status of the individual such that husbands and wives have access to different amounts of money and potentially different standards of living).

${ }^{93}$ See geneally Regina Austin, Of Predatory Lending and the Democratization of Credit: Preserving the Social Safety Net of Informality in Small-Loan Transactions, 53 AM. L. REV. 1217 (2004). 


\section{Draft-Money Paper}

\section{Regina Austin - Penn Law}

May 15, 2012

and crime. ${ }^{94}$ This requirement (which was directed at exposing criminal activity) reduces cash's currency or capacity to circulate as a medium of exchange and accordingly reduces its value. ${ }^{95}$ The decrease in efficacy impacts large amounts of cash that are lawfully acquired, even if they are too small to trigger the reporting requirement. This particularly affects the money of minority working class people whose savings take the form of cash because they distrust or do not understand financial institutions. ${ }^{96}$

History, contemporary statistics, and anecdotal evidence support the idea of their being a symbolic linkage between black people’s money and cash. For most of our history in America, blacks have constituted a near caste, confined to the lowest ranks of the social and economic sectors by the compounding confluence of class and race. Unpacking the link between the two is a difficult process. A steadily growing black middle class is still treated as exceptional by the media. Blacks continue to lag behind whites with regard to wealth accumulation.

The connection between cash and black people’s money may explain why black wealth is rendered invisible. There is no presumption that an African American possesses money in quantity and in its more exalted forms; as a result, an African American, even if relatively rich in fact, does not possess the financial credibility that can smooth commercial transactions. The assumption that blacks primarily have cash to spend is hard

${ }^{94}$ Bank Secrecy Act of 1970, 31 U.S.C. §§ 5311-5324 (1994); 31 C.F.R. § 103.22 (2000).

${ }^{95}$ Edward L. Rubin \& Robert Cooter, The Payment System: Cases, Materials and Issues 84 (2d ed. 1994).

${ }^{96}$ This point was made by a Milwaukee consumer credit activist who said, in describing continuing barriers to credit, that "some lenders still question where a minority could get money for a down payment particularly when it is in cash. .. [I]n her culture (she is a Latina) some Mexicans do not trust banks. So they keep money at home 'in coffee cans." Squires \& O’Connor, supra note $\underline{32}$, at 20. In her view, though, lenders were increasingly finding such "mattress money" to be acceptable. Id. 


\section{Draft-Money Paper}

\section{Regina Austin - Penn Law}

May 15, 2012

to overcome. Money is a good or commodity that one's group has to be identified with in order for it to have the maximum social/material power in any individual's hands. ${ }^{97}$

Variations on the theme of the cash/crime connection work to taint black people's money in general, not just their cash. Blacks' participation in the spheres of legitimate or formal production tends to be underappreciated or constructed as forms of deviance. ${ }^{98}$ Moreover, blacks are often portrayed as a kind of "leisure class" whose recreational or pleasure activities, even when they prove to be remunerative, are considered excessive and disruptive of the social order and therefore in need of extensive regulation. ${ }^{99}$ Finally, the delegitimation of affirmative action and minority set-asides promotes the idea that even successful, highly educated black professionals and entrepreneurs do not come by their money fairly or scrupulously. As a result, large amounts of black money, in whatever form, bear a blemish of illegality and illegitimacy and suffer an accompanying impaired currency and devaluation, just like cash.

A good example of how doubts about the way blacks earn their money diminish its worth is reflected in the ambivalent attitudes whites hold toward highly paid black male

\footnotetext{
${ }^{97}$ Money has some of the characteristics of an associative good. An associative good is one that a consumer selects not only because of its quality and price, but also because of the status of the other consumers of the product who are a source of social and cultural capital that enhance the return from the transaction. See Henry Hansmann, The Ownership of Enterprise 185 (1996). A social club membership and a university education are typical associative goods. $I d$. The purveyor of an associative good, in turn, is also concerned with the personal quality or characteristics of its customers. Id. at 187. Customers of higher quality will make the firm's goods more attractive to other high status consumers. As the discussion that follows suggests, black people's money bears the burden of their possessors' association with other black people who are not assumed to be financially sophisticated or economically successful and therefore it does not have attached to it as much social and cultural capital as white people's money.

${ }^{98}$ See, e.g., Regina Austin, “A Nation of Thieves”: Securing Black People’s Right to Shop and to Sell in White America, 1994 Utah L. Rev. 147 (analyzing the mechanism by which both black consumption and production, particularly commerce, are constructed as forms of deviance both without and within black culture).

${ }^{99}$ See Austin, Governmental Restraints on Black Leisure, supra note 14.
} 


\section{Draft-Money Paper}

\section{Regina Austin - Penn Law}

May 15, 2012

professional athletes. At the same time that these men are praised, even idolized, as entertainers of the white masses, they are belittled and held in contempt for their large salaries, conspicuous consumption, au fait street ways, and even their athletic abilities. ${ }^{100}$ Black athletes, more than white ones, are said to be capitalizing on their natural physical prowess as opposed to their intellectual endowments, whether they are educated or not. As a result, black athletes are stigmatized as being undeserving of the inflated salaries they are paid, as well as too ignorant and unsophisticated to know what to do with all that money. ${ }^{101}$ Black female basketball players do not make the same pay and are exempt from the economic criticism, though they have other crosses to bear related to their race, gender, and sexual orientation. ${ }^{102}$ Athletes and entertainers who allow their white

${ }^{100}$ See Todd Boyd, Mo’ Money, Mo’ Problems: Keepin’ It Real in the Post-Jordan Era, in Basketball Jones: America Above the Rim 59, 65 (Todd Boyd \& Kenneth L. Shropshire eds., 2000) (arguing that while it is acceptable for young black male athletes to entertain whites, the athletes are held in contempt for the money they make); David Shields, Black Planet:

Facing Race During an NBA Season 55, 69, 119-20, 125, 126 (1999) (documenting fans'--and the author's--admiration and resentment of African American basketball players who appear to have everything, including a "triumphant blackness."). See also Timothy Davis, Racism in Athletics: Subtle Yet Persistent, 21 U. Ark. Little. Rock L. Rev. 881, 888-89 (speculating that “animosity toward highly paid African American athletes who are perceived as unworthy" may be the product of "bias toward blacks who achieve high status and opposition to black progress").

${ }^{101}$ See Jayson Williams, Loose Balls: Easy Money, Hard Fouls, Cheap Laughs, and True Love in the NBA (with Steve Friedman) 87-89 (2000) (advancing a player's balanced defense of the high salaries of basketball players in the face of criticism). In the minds of the players, money compensates for the indignities they experience as performers and as black men in general and enables them to adopt a stance of "calculated indifference" to the abuse. Boyd, supra note 100, at 65-66. According to Todd Boyd, "the players make enough money to be able not to give a fuck, as money is the ultimate source of liberation in capitalist America.” Id. at 66. See also Williams, supra at 91-92 (arguing that money compensates for the indignity of whites' stigmatization of black athletes as stupid and inarticulate).

${ }^{102}$ See Tara McPherson, Who's Got Next? Gender, Race, and the Mediation of the WNBA, in Basketball Jones, supra note $\underline{100}$, at 184 (contending that black female professional basketball players are contextualized by the WNBA in a sphere of almost suburban domesticity that presents them as caring and cooperative, like the game they pay, in contrast to the male players who are urban, aggressive and out-of-control). 


\section{Draft-Money Paper}

\section{Regina Austin - Penn Law}

May 15, 2012

audiences "to forget” that they are black are exempted from the disparagement of their right to extract sizeable economic gains from their performances. ${ }^{103}$

The two strains of belief that produce the black money/cash nexus-that blacks do not have much money and what money they have is tainted-often come together to diminish the value of black people's money. The convergence creates obstacles and limitations that may make it nearly impossible for those who do business with black money to move beyond the cash economy. For example, blacks have been barred from paying for purchases by check at retail outlets concerned about check fraud; sometimes the prohibition applies to black (but not white) customers and sometimes the prohibition is based on the composition of the community in which the store is located. ${ }^{104}$ I suspect, but cannot prove, that black customers are also more likely to be asked for proof of

${ }^{103}$ See generally David L. Andrews, The Fact(s) of Michael Jordan's Blackness: Excavating a Floating Racial Signifier, 13 Soc. Sport J. 125 (1996) (describing how Michael Jordan escaped criticism as long as he was cast in the popular media as an All-American, middle-class, well-spoken, non-threatening hero who displaced and transcended the race of his peers).

${ }^{104}$ See Sharon Linstedt, Family Dollar to Accept Checks at Inner-city Stores, Buffalo News, June 2, 2000, at A7 (announcing a settlement reached by the attorney general of New York ending a retailer's practice of rejecting checks at stores with large minority populations); Ann Mariano, Kinney to Pay $\$ 100,000$ to Settle Suit, Women Accused Foot Locker Stores of Bias; Youth Groups to Get Funds, Wash. Post, Jan. 7, 1994, at G1 (reporting on the settlement of a discrimination suit that arose from the retailer's refusal to accept checks from black customers issued by D.C. banks). See also Buchanan v. Consolidated Stores Corp., 125 F. Supp.2d 730 (D. Md. 2001) (denying dismissal of a $\S 1981$ action brought by shoppers who were denied the right to pay for purchases by check at stores located in predominately black areas); Kathleen Schalch, Class Action Lawsuit Filed Against KB Toys after Stores in Predominately Black Neighborhoods Refused to Take Checks, NPR, Mar. 6, 2000, available at 2000 WL 21479898 (reporting on an action based on the retailer's discriminatory check acceptance policy which the company defended on the ground of actual negative experience with bad checks, not demographics). 


\section{Draft-Money Paper}

\section{Regina Austin - Penn Law}

May 15, 2012

identification before they are allowed to pay for a purchase with a credit card and the authenticity of their cash (their $\$ 20$ or $\$ 50$ bills) is also more likely to be questioned. ${ }^{105}$

Finally, consider “Driving While Black” or “DWB,” a form of racial profiling practiced by law enforcement officers on America’s highways. Many an upstanding middle-class African-American has been stopped by the police because of the mistaken belief that blacks cannot afford to drive very expensive, late-model cars unless they are involved in illegal drug trafficking. ${ }^{106}$ This assumption is also expressed in other contexts. For example, in Ellis v. Safety Ins. Co., ${ }^{107}$ the plaintiff was a black woman who reported to her insurer that her Jaguar had been stolen. The investigator assigned to the claim suspected that it was fraudulent and asked both the insured and her mother how black people could afford such an expensive car. An appellate court allowed the plaintiff to proceed with an action against her insurer and its investigator based on slander, unfair business practices, and violations of her civil rights.

In sum, then, the symbolic association of black people's money with cash reduces its social clout and its material value by facilitating efforts to confine and funnel transactions conducted with black money into the cash economy. The association also makes it more difficult for blacks to establish believability and trust with regard to

${ }^{105}$ I recently offered a salesclerk an old $\$ 20$ bill to pay for a $\$ 14.00$ purchase. The salesclerk questioned the authenticity of the currency. I offered her any of the sixteen newer \$20 bills I had in my possession, but she refused them. She took my bill and disappeared somewhere in the back of the store with the purpose of verifying the bill's authenticity. Upon returning to the cash register, she informed me that the bill was genuine and proceeded to give me my change. I demanded an explanation and an apology from the manager which I did not get. I immediately e-mailed and called corporate headquarters; the chief of human resources and customer relations informed me that the day before the store has received six bogus $\$ 20$ from, I assume they assume, a black woman. The black manager of the store had ordered the clerks to exercise heightened scrutiny. Unfortunately, the first person targeted by this policy was me.

${ }^{106}$ See David A. Harris, Profiles in Injustice: Why Profiling Cannot Work 22 (2002) ("use of a large late model car or rental car" was one of the elements of the original Florida Highway Patrol drug-courier profile).

10741 Mass.App.Ct. 630, 672 N.E.2d 979 (1996). 


\section{Draft-Money Paper}

\section{Regina Austin - Penn Law}

May 15, 2012

transactions involving substantial sums of money or necessitating credit. Credit or other people's money is also harder to obtain. Conversely, it is easier for others to negotiate or bargain successfully with blacks if black people's money is treated like cash or its equivalents. The money would obviously be put to a better, higher use in the hands of a nonblack person. Moreover, the money is tainted by the association between blacks and crime and dishonesty and, as with a fetish subject to a taboo, is sanitized or restored to full value when it passes into the hands of others.

(7) Money as Evil: A Taboo from the Other Side

To some extent, the attitudes toward risk and patterns of financial behavior displayed by blacks reflect a culture that disseminates, through numerous media (popular fiction, folklore, cinema, music, even sermons), the message that money is a potentially morally corrupting influence. Money is associated with evil, exploitation, futility, and corruption. ${ }^{108}$ Thus, efforts to sell or commodify black culture, especially art, music, and dance, which might be beneficial in producing markets blacks control and increasing the social and material potency of black dollars, have been criticized as alienating and coopting. ${ }^{109}$ Black people who have what is considered a lot of money are accused of forgetting where they came from and stigmatized for losing their race consciousness. Their money and their competitive individualism are viewed as a threat to community solidarity. ${ }^{110}$ Wealthy blacks are urged to "give back" to "the community" in the form of

${ }^{108}$ See George Subira, Black Folks Guide to Business Success 50-74 (1986)

(discussing a score of attitudes that relate to money and entrepreneurship).

${ }^{109}$ See Regina Austin, Kwanzaa and the Commercialization of Black Culture (1995) (unpublished manuscript, on file with author).

${ }^{110}$ The anti-money bias in black culture was explored by Sharon A. Lewis, in her Ph.D. dissertation which analyzed Zora Neal Hurston's Their Eyes Were Watching God, Toni Morrison's The Bluest Eye and Paule Marshall's Praise Song for the Widow. See Sharon A. Lewis, Spyin’ Noble: Money in Novels by Black American Women (unpublished Ph.D. dissertation, Rutgers, The State University of New Jersey, 1996). According to Lewis, these works reflect the idea common in black culture and sociological literature that the pursuit of material advancement by the black middle class jeopardizes its ties to the black community and 


\section{Draft-Money Paper}

\section{Regina Austin - Penn Law}

May 15, 2012

charity, networking, and employment opportunities. In essence, well-off blacks are urged to build up their portfolio of "symbolic capital"111 and through their generosity, save their souls. This sort of exhortation is not unique to African Americans, of course. ${ }^{112}$ Taken to extremes, though, the obligation to "give back" can impose a substantial cost or "tax"113 on blacks doing business, in particular with each other, and be a drag on black economic development. On the other hand, the admonition to give back represents a recognition of the social origins of wealth and money's material worth.

On the surface, the anti-money bias that is an aspect of black culture appears to be a justified critical response to the role money has played in the domination of a people, most of whose ancestors came to this country as white people's property. However, the direction of the criticism at economically successful blacks, as opposed to the institutions of the white, male-dominated economic establishment, suggests that its analytical edge is less sharp than it needs to be. Blacks must give greater thought to determining how individual moneymaking can be made more compatible with, or a component of, group advancement in an economy where big money is not a wad of bills, but cybermoney which travels faster than the speed of light. The anti-money bias is perfectly consistent

its respect for and memory of its cultural heritage. Lewis found the texts to be wanting in that they failed to recognize the relationship between money and "survival, stability, and achievement.” Id. at 202. Lewis calls for a "critique which dares to explore what might be meaningful, wholesome, useful, promising about Black middle[-class] life.” Id. at 205.

${ }^{111}$ Symbolic capital is honor or prestige that is generated by supposedly disinterested charity or largess. It creates a debt on the part of the recipients on which the giver may at some point call. The role played by the material self-interest of the giver is disguised. See generally Pierre Bourdieu, The Logic of Practice 112-120 (Richard Nice trans. 1990); Carolyn Betensky, The Prestige of the Oppressed: Symbolic Capital in a Guilt Economy, in Pierre Bourdieu: Fieldwork in Culture, supra note ?, at 207, 208. Business people might label symbolic capital "generalized goodwill."

${ }^{112}$ Light \& Gold, supra note $\underline{80}$, at 126-27 (citing studies dealing with Dominican, Puerto Rican, and Chinese Americans).

${ }^{113}$ See Jones, supra note $\underline{78}$, at $680-81$. 


\section{Draft-Money Paper}

\section{Regina Austin - Penn Law}

May 15, 2012

with a cash-basis focus that considers financial transactions a significant form of positive, self-affirming interaction crucial to communal life. Increasing the value of black money, however, will require that blacks transport some of the humanistic values that do or should characterize face-to-face cash-basis exchanges into the larger, less personal realms of the economy that are not tied to cash. To increase the value of their money, blacks must come to look upon money and its institutions and actors with less suspicion and more optimism about the possibility that they can be made accountable through political and social activism. The same sort of moral indignation and insightful, thoroughgoing criticisms that fueled the civil rights movement must be mustered in an assault on money's institutions and actors.

Black economist Glenn Loury has argued that "[i]t is time to integrate the money." 114 In Loury’s view, integration requires that blacks not only become conversant with the institutions of modern finance, they must also, in some way, come to "believe in" them. ${ }^{115}$ Blacks’ beliefs would change, of course, if the institutions delivered on the promise of integration and showed themselves to be more responsive to pleas of economic inequality and social injustice. At the same time, it should be apparent that neither fulfillment of the promise of integration nor greater institutional responsiveness is likely to be achieved unless blacks alter their discursive practices to reflect a more positive interest in money and all its machinations.

Prior to the recent downturn in the stock market, the material times favored investing and wealth accumulation. The black public sphere seems to have discovered money and its institutions. Blacks are striving to acquire the information they lack by virtue of a limited historical involvement in or even familiarity with the various aspects of the financial sector. Blacks are going to seminars, reading books and magazines, and starting investment clubs. The question is whether their preoccupation with money and

\footnotetext{
${ }^{114}$ Id. at 71.

${ }^{115} I d$.
} 


\section{Draft-Money Paper}

\section{Regina Austin - Penn Law}

May 15, 2012

financial markets goes beyond individual self-interest. That blacks are once again talking about seeking reparations for the damage slavery and segregation inflicted on African Americans is a positive sign that a larger agenda is in the offing. ${ }^{116}$ Indeed, the relationship between the past and the present might supply a useful rhetorical hook for redirecting black discourse on money.

Anthropologist Keith Hart, who coined the term “informal economy,” has described money as being “an aid to memory," 117 "an act of remembering, a way of keeping track of some of the exchanges we have entered into with the rest of humanity." ${ }^{118}$ Hart asserts that "the need to keep track of proliferating connections with others is mediated by money in its many forms as the principal instrument of collective memory." Viewed in this light, money represents the sum total of all the transactions involving the unpaid labor and suffering for which blacks, by virtue of their enslavement and domination, were unable to demand contemporaneous recompense. Money symbolizes all that has been done to blacks and all that blacks have done or contributed to its accumulation. Contemporary blacks’ attempt to hold the financial institutions accountable for a history of exploitation and domination of their ancestors here and

${ }^{116}$ See generally Randall Robinson, The Debt: What America Owes to Blacks (1999) (arguing that simply demanding reparations would improve blacks' psychic well-being, as well as disrupt the "habit" of blacks and whites seeing each other "in a certain relation of economic and social inequality”); Note, Bridging the Color Line: The Power of African-American Reparations to Redirect America's Future, 115 Harv. L. Rev. 1689 (2002) (arguing that blacks' quest for reparations should emphasize group-based redress rather than individual recoveries and political activity rather than litigation); The Case for Reparations, Ebony, Aug. 2000, at 70 (featuring short statements by U.S. Rep. John Conyers, who authored a bill proposing the establishment of a commission to consider the subject; Chicago Alderman Dorothy Tillman, who sponsored a resolution urging Congress to consider the Conyers' bill; and Randall Robinson); Diane Cardwell, Seeking Out a Just Way to Make Amends for Slavery, N.Y. Times, Aug. 12, 2000, at B7 (presenting a range of views on the subject of black reparations).

${ }^{117}$ Hart, supra note $\underline{91}$, at 260.

${ }^{118} I d$. at 234. 


\section{Draft-Money Paper}

\section{Regina Austin - Penn Law}

May 15, 2012

abroad might be viewed as an act of reclamation and reconciliation. It is a way of humanizing money.

While blacks’ alienation and estrangement from money are understandable in light of blacks' history, there is a need to forgive money in order to seize a measure of control over it. Otherwise, black people risk being left further behind as money continues to accumulate debts and credits. It is not necessary that blacks come to believe in financial institutions as they are presently constituted. We must, however, understand the economic institutions and actors who hide behind money's veneer of social and political impregnability and call those institutions and actors to account. The goal ought to be, as Hart suggests, "to improve the scope for human beings to see themselves as free economic agents; to make it more possible for people to express their personalities in social life; and to build up the stable infrastructures of money, law, education and technology capable of providing impersonal guarantees of such activity." ${ }^{119}$ Blacks need to have some belief in money, if for no reason other than to demand that money's institutions work toward the achievement of the economic emancipation of the least welloff people in our society. This should be the premise on which the challenge to the devaluation of black people’s money proceeds.

\section{(8) Conclusion: Talking Up Black People’s Money}

There are some measures that lawyers might employ to help tort plaintiffs like Mrs. Wright and Mr. Hill whose recoveries are impacted by the lower social and material value of black people's money. They parallel the devices individual blacks use to enhance the clout of their money in simple consumer transactions. For example, blacks and/or women may have a better chance of receiving full value for their money in transactions in which their race and/or gender are hidden, as when they engage in

${ }^{119}$ Id. at 313. 


\section{Draft-Money Paper}

\section{Regina Austin - Penn Law}

May 15, 2012

commerce on the Internet or over the phone ${ }^{120}$ or when they use white male fronts, covers, ghosts, or agents to do business for them. ${ }^{121}$ Likewise, in court cases involving guardianships, a white male executive from the trust department of the local big bank seated at the plaintiff's table may ward off any suspicion on the part of the jury that the millions they should award in damages to a black victim will be misspent.

Transactions conducted in black-dominated or female-dominated markets in which the dollar is "super-racialized”or "super-genderized" may produce fairer or less discriminatory transactions. ${ }^{122}$ Similarly, if there is a choice with regard to the venue in which a suit might be brought, minority plaintiffs may achieve fairer or less discriminatory settlements and verdicts in locales where the jurors are likely to be either minorities themselves or sympathetic to minorities. Affinity may mean something where jurors are concerned. As one torts commentator put it, "serious personal injury cases [offer] one of the few opportunities that most people of color have to make an immediate

${ }^{120}$ See Ayres, supra note $\underline{73}$, at 156-57 (describing the use of Internet car sales, particularly by women, but also questioning whether the Internet will affect the prices paid by less sophisticated shoppers). See also Jerry Kang, Cyber-Race, 113 Harv. L. Rev. 1130, 118895 (imaging a zone in cyberspace in which racial distinctions are totally abolished in order to promote color-blind e-commerce).

${ }^{121}$ See Ayres, supra note 73, at 151 \& note 85 (citing a "dramatic growth in third party buying services which negotiate for car purchasers); but see id. at 84, note 104 (suggesting that entrepreneurs selling negotiation services may have "a hard time communicating both that a problem exists and that their service provides a solution" while consumers of such services may encounter difficulty confirming that they have paid a competitive price). Blacks on the other side, the selling side, of transactions may resort to similar devices. See Angelo B. Henderson, Black Entrepreneurs Face a Perplexing Issue: How to Pitch to Whites, Wall St. J., Jan. 26, 1999, at A1 (reporting that black-owned firms employ whites to sell services, do commercials, run franchises, and do business with other whites as a way of combating discrimination).

${ }^{122}$ Professor Ayres's study of car purchase negotiations suggests that impact of the race of the seller and that of the buyer on pricing is fairly complex. Blacks did not fare better at black-owned dealerships than at white ones, but they did pay lower prices at dealerships in black neighborhoods. Ayres, supra note $\underline{73}$, at 73. The race of the salesperson mattered only for black female testers who were "systematically quoted higher final prices when buying from black salesmen." Id. at 72. 


\section{Draft-Money Paper}

\section{Regina Austin - Penn Law}

May 15, 2012

economic impact in favor of an injured member of the community and send a message to corporations and other powerful social players.”123

If venue cannot be chosen, the attorney may be dependent upon either voir dire to weed out jurors whose notions of the social meaning of money will work to a minority plaintiff's detriment or jury instructions to keep the impulse under control, if any references to race and money are allowed at all. ${ }^{124}$ Instructions might backfire, though; raising the issue in a cautionary way might produce just the opposite reaction in white jurors. Stereotype-reinforcing information about the lifestyle or financial practices of a minority litigant should be kept out of evidence, just as questions concerning convictions might be barred where the witnesses come from minority groups.

A lawyer who represents both plaintiffs and defendants told me that jurors like claimants who fit the American ideal of the good citizen and so he tries to present his clients in this light. More highly educated, better spoken middle-class minority claimants do better than their poorer, less well-educated counterparts. Jurors are more sanguine about putting money in the hands of the former. Work history matters; a person with a spotty employment background will get less. With Latino clients, this attorney emphasizes their long tenure in this country, as well as the fact that they speak English and are employed. This counters the invidious stereotype that Latinos are largely illegal

${ }^{123}$ McClellan, supra note $\underline{19}$, at 785 . The evidence regarding the impact of race and locale on the prevalence of plaintiff's verdicts and the amounts awarded is equivocal, however. Cornell professors Theodore Eisenberg and Martin Wells empirically tested the widespread supposition that "[m]inorities favor injured plaintiffs and give them inflated awards." Theodore Eisenberg \& Martin T. Wells, Trial Outcomes and Demographics: Is There a Bronx Effect?, Tex. L. Rev. -----, 1 (2002). Demographics did not explain trial outcomes in the bulk of cases. However, higher black population percentages were correlated with a higher rate of victories for plaintiffs in urban job discrimination cases in federal courts. Contrary to the supposition, though, there was "a negative relation between award levels and black population percents.” Of course, litigants in poorer venues may be poor themselves and therefore entitled to lower damages. Also, black jurors are not immune from attributing a lower social value to other black people's money.

${ }^{124} \mathrm{Id}$. at 780. 


\section{Draft-Money Paper}

\section{Regina Austin - Penn Law}

May 15, 2012

immigrants who are unemployed. This attorney keeps his clients in check; the client is told to remain controlled at all times and to act like a highly respectable Negro or

Hispanic. Convincing clients, on the other hand, that the courtroom is not a hostile place and that justice can be found there if they present themselves in the "correct" way is not always easy, though, given the fear of institutions and white authority figures in general and courts in particular harbored by many minority people.

Finally, courts should exercise more oversight of damage awards in cases involving women, minorities, and the poor. The standards for granting motions for additur or a new trial on account of inadequate damages are generally quite tough, ${ }^{125}$ but

${ }^{125}$ Typically, under state law, a plaintiff may challenge the inadequacy of a jury verdict with a motion for additur or in the alternative a new trial. Additur allows the court to deny the plaintiff's motion for a new trial conditioned on the defendant's consent to an increase in the amount of the jury's award. See, e.g., ITT Hartford Ins. Co. v. Owens, 816 So. 2d 572 (Fla. 2002) (finding that the insurer was entitled to a new trial on the issue of the insured's future medical expenses because it rejected additur). Additur is not generally available in federal actions, however, because it infringes the right to a jury trial that is guaranteed by the Seventh Amendment, see Dimick v. Schiedt, 293 U.S. 474 (1935), although additur may be granted to increase damages to an amount that is undisputed, definite, and incontrovertible, see, e.g., United States EEOC v. Massey Yardley Chrysler Plymouth, Inc., 117 F.3d 1244, 1252-53 (11th Cir. 1997) (increasing a back pay award in an ADEA action where there was no genuine issue as to the correct amount of damages), or to correct mistakes of law as where the jury was not told that it must grant at least nominal damages. See, e.g., Gibeau v. Nellis, 18 F.3d 107 (2d Cir. 1994) (remanding for the award of \$1 in nominal damages where a prisoner proved excessive use of force in violation of the Eighth Amendment, but not actual causal injury); Jimenez v. Paw-Paw's Camper City, Inc., 2002 WL 257691 (E.D. La. 2002). Federal courts sitting in diversity may offer the defendant the remedy of additur if it is available under the laws of the forum state. Gasperini v. Center for Humanities, Inc., 518 U.S. 415 (1996).

The standards for granting additur or a new trial based on the inadequacy of the verdict are the same. The federal courts and many state courts award plaintiff's relief only when the verdict is against the clear weight of the evidence as where it shocks the conscience, represents a miscarriage of justice, or shows passion or prejudice. See, e.g., Scott Prather Trucking, Inc. v. Clay ex rel Sanders, 2002 WL 827632 (Miss. 2002) (affirming an award of additur that increased damages to $\$ 150,000$ from $\$ 35,800$ which was “contrary to the overwhelming weight of the evidence in a case involving the facial disfigurement of a young woman). The courts in New York are subject to a somewhat different standard. Under statute, New York courts may grant a new trial if the award "deviates materially from what would be reasonable compensation." See N.Y. C.P.L.R. § 5501 (c) (200x); Geressy v. Digital Equipment Corp., 980 F. Supp. 640 


\section{Draft-Money Paper}

\section{Regina Austin - Penn Law}

May 15, 2012

courts should be vigilant in protecting claimants whose recoveries appear to have been diminished by the social meaning attached to money in their hands. ${ }^{126}$

The fictions regarding money’s fungibility and economic rationality mask the socially and culturally discriminatory significance attached to money. They force poor people and/or minorities especially to negotiate their participation in economic life and to construct their economic identities in a quagmire of stereotypes and assumptions that reduce the value of the dollars they are able to command. Their economic advancement depends on the development of competitive public spheres in which their money can be put to work for them in a way that enhances their material well-being and generates the moral and social infrastructure that will support a good life for them and, if for them, then for nearly everyone else as well. A first step in achieving this goal should entail accepting the premises advanced here, namely that, by virtue of segregated markets and cultural practices, there is such a thing as black people's money and that it is worthless

(E.D.N.Y. 1997). See also David Balbus et al., Improving Judicial Oversight of Jury Damages Assessments: A Proposal for the Comparative Additur/Remittitur Review of Awards for Nonpecuniary Harms and Punitive Damages, 80 Iowa L. Rev. 1109 (1995) (urging greater scrutiny of unreasonably low awards by reference to the range of amounts granted in other cases).

Explicit guidelines governing the trial judge's discretion in adjusting the damages are rare. A recent Delaware court suggested that the defendant should be accorded the benefit of every reasonable factual inference supporting the verdict and that the court should award the lowest amount supported by the evidence. Breeding v. Johnson, 1992 WL 148005 (Del. Super. Ct. 1992).

${ }^{126}$ For example, the court might have granted plaintiff's motion for additur in Rivera v. St. Rose's Church of New Haven, 2000 WL 872455 (Conn. Super. Ct. 2000). The jury had awarded the plaintiff over $\$ 11,000$ in economic damages, but only $\$ 8,000$ in noneconomic damages which the court admitted was "very low.” Id. at *1. The defendant, a Catholic school, had been improperly characterized as a "poor school” by its principal but this remark did not provoke a request for a curative instruction or a mistrial from plaintiff's lawyer. Id. The court raised the fact that "the plaintiff was an inner city minority male who did not exude ambition or polish;” furthermore it said "[t]hat this may have affected the largely middle-class jury is a concern and troubling." Id. The court nonetheless did not find the verdict inadequate because the injury did not hamper the plaintiff's present or future activities or his earning capacity, nor did he experience much pain. $I d . * 1-* 2$. 


\section{Draft-Money Paper}

\section{Regina Austin - Penn Law}

May 15, 2012

than white people's money; that black people's money is the product of the agency of blacks and whites and others alike; and finally, that whatever divisions and distinctions people create, including those related to the most sacred or magical of commodities, i.e., money, they can modify, ameliorate, and destroy, if they have the will to do it. 